\title{
Bilateral carotid arteries occlusion
}

\author{
Toshikazu Abe, ${ }^{1}$ Yasuharu Tokuda ${ }^{2}$
}

1 Department of Emergency and Critical Care Medicine, Mito Kyodo General Hospital, University of Tsukuba, Mito, Japan

${ }^{2}$ General Internal Medicine, Tsukuba University, Mito, Japan

\section{Correspondence to}

Dr Toshikazu Abe,

mican-philia@sunny.ocn.ne.jp
A 95-year-old woman came to our hospital by ambulance because she suddenly fell into coma when she was drinking tea. She had no history of medical diseases including arrhythmia, hypertension, dyslipidemia and diabetes, and she had no

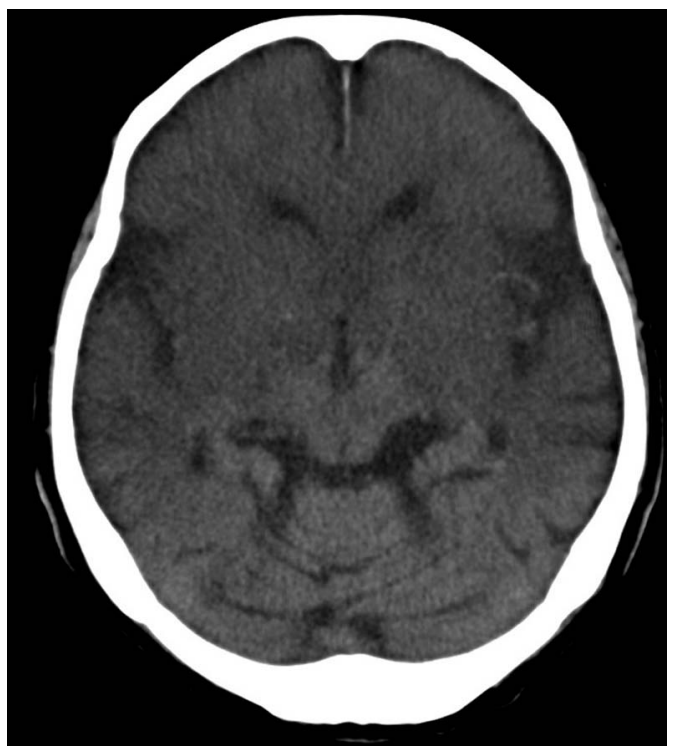

medications. Neurological examination revealed decerebrate rigidity and bilateral Babinski signs. CT on one day after admission demonstrated broad low-density area in the bilateral cerebral hemispheres, including the area of bilateral anterior cerebral artery and middle cerebral artery, but sparing the brainstem and occipital lobe (figure 1). Bilateral internal carotid artery embolisation was identified according to the results of autopsy.

\section{Competing interests None.}

Patient consent Obtained.

Provenance and peer review Not commissioned; externally pee reviewed.

Figure 1 Plain computed tomography (CT) brain on one day after admission.
Copyright 2013 BMJ Publishing Group. All rights reserved. For permission to reuse any of this content visit http://group.bmj.com/group/rights-licensing/permissions.

BMJ Case Report Fellows may re-use this article for personal use and teaching without any further permission.

Become a Fellow of BMJ Case Reports today and you can:

- Submit as many cases as you like

- Enjoy fast sympathetic peer review and rapid publication of accepted articles

- Access all the published articles

- Re-use any of the published material for personal use and teaching without further permission

For information on Institutional Fellowships contact consortiasales@bmjgroup.com

Visit casereports.bmj.com for more articles like this and to become a Fellow 